\title{
Effect of urbanisation on asthma, allergy and airways inflammation in a developing country setting
}

\author{
Colin L Robinson, ${ }^{1,2}$ Lauren M Baumann, ${ }^{1,2}$ Karina Romero, ${ }^{2}$ Juan M Combe, ${ }^{2}$ \\ Alfonso Gomez, ${ }^{2}$ Robert H Gilman, ${ }^{2,3,4}$ Lilia Cabrera, ${ }^{2}$ Guillermo Gonzalvez, ${ }^{4}$ \\ Nadia N Hansel, ${ }^{1,5,6}$ Robert A Wise, ${ }^{1}$ Kathleen C Barnes, ${ }^{1,5}$ Patrick N Breysse, ${ }^{6}$ \\ William Checkley ${ }^{1,2,3,4}$
}

\section{See Editorial, p 1025}

- Additional materials are published online only. To view these files please visit the journal online (http://thorax.bmj. com)

${ }^{1}$ Division of Pulmonary and Critical Care, Department of Medicine, Johns Hopkins School of Medicine, Baltimore,

Maryland, USA

${ }^{2}$ AB PRISMA, Lima, Perú ${ }^{3}$ Department of Internationa Health, Program in Global Disease Epidemiology and Control, Johns Hopkins Bloomberg School of Public Health, Baltimore, Maryland USA

${ }^{4}$ CRONICAS Center of Excellence for Chronic Diseases, Universidad Peruana Cayetano Heredia, Lima, Peru ${ }^{5}$ Division of Allergy and Clinical Immunology, Johns Hopkins School of Medicine, Baltimore, Maryland, USA

${ }^{6}$ Department of Environmental Health Sciences, Johns Hopkins Bloomberg School of Public Health, Baltimore, Maryland, USA

\section{Correspondence to}

William Checkley, Division of Pulmonary and Critical Care, Johns Hopkins University, 1830 Monument Street, Fifth Floor, Baltimore, MD 21205, USA wcheckl1@jhmi.edu

Received 5 January 2011 Accepted 2 June 2011 Published Online First

5 July 2011

\section{ABSTRACT \\ Background Asthma is a growing public health problem in developing countries. However, few studies have studied the role of urbanisation in this phenomenon. It was hypothesised that children living in a peri-urban setting in Peru have higher rates of asthma and allergy than rural counterparts.}

Methods 1441 adolescents aged 13-15 years were enrolled from two settings: a peri-urban shanty town in Lima $(n=725)$ and 23 rural villages in Tumbes $(n=716)$. Participants filled in questionnaires on asthma and allergy symptoms, environmental exposures and sociodemographics, and underwent spirometry, and exhaled nitric oxide (eNO) and allergy skin testing. Indoor particulate matter (PM) concentrations were measured in 170 households.

Results Lima adolescents had higher rates of lifetime wheezing $(22 \%$ vs $10 \%)$, current asthma symptoms ( $12 \%$ vs $3 \%$ ) and physician-diagnosed asthma (13\% vs $2 \%$; all p $<0.001)$. Current rhinitis $(23 \%$ vs $12 \%)$, eczema ( $12 \%$ vs $0.4 \%)$, atopy (56\% vs $38 \%$ ), personal history of cigarette smoking $(7.4 \%$ vs $1.3 \%)$ and mean indoor PM (31 vs $13 \mu \mathrm{g} / \mathrm{m}^{3}$ ) were also higher in Lima (all $p<0.001$ ). The peri-urban environment of Lima was associated with a 2.6-fold greater odds ( $95 \% \mathrm{Cl} 1.3$ to 5.3) of asthma in multivariable regression. Forced expiratory volumes were higher and $\mathrm{FEV}_{1} / \mathrm{FVC}$ (forced expiratory volume in $1 \mathrm{~s} /$ forced vital capacity) ratios were lower in Lima (all $p$ $<0.001)$. Higher eNO values in Lima $(p<0.001)$ were attributable to higher rates of asthma and atopy.

Conclusions Peri-urban adolescents had more asthma, atopy and airways inflammation and were exposed to more indoor pollution. The findings provide evidence of the risks posed to lung health by peri-urban environments in developing countries.

\section{INTRODUCTION}

Asthma is widely recognised for its high prevalence and public health importance in developed countries. ${ }^{1}$ It is estimated to affect 300 million individuals worldwide, ${ }^{2}$ and its burden in disability-adjusted life years lost is comparable with that of diabetes mellitus or cirrhosis. ${ }^{2}$ Risk factors for asthma include allergic symptoms, ${ }^{3-5}$ atopy $^{3}$ and elevated total serum immunoglobulin $\mathrm{E}$ (IgE). ${ }^{6}$ Urbanisation has become recognised as an important contributor to childhood asthma. ${ }^{7-9}$ Some purport that urbanisation leads to increased asthma due to higher levels of air pollution including particulate matter (PM) ${ }^{10}$

\section{Key messages}

What is the key question?

- We wanted to know whether the trend for increased urbanisation in developing countries could account in part for the increasing prevalence and morbidity of asthma.

\section{What is the bottom line?}

- Our study showed that adolescents living in a peri-urban environment had increased levels of atopy, asthma and airway inflammation compared with their counterparts living in a rural environment.

\section{Why read on?}

- The peri-urban environment of Lima conveyed a nearly threefold increased risk of current asthma. The higher levels of indoor air pollution may contribute to these findings.

while others have pointed to changes in diet. ${ }^{11} 12$ Others hypothesise that exposure to fewer parasitic infections or a greater number of viral infections early in life while the immune system is developing may play a role in asthma risk. ${ }^{9}$ As many major urban centres in the developing world are undergoing rapid growth accompanied by increases in outdoor air pollution, the incidence and burden of asthma are also likely to increase.

The effect of urbanisation on asthma risk is well known; however, few studies have been conducted in low- and middle-income countries. Moreover, unique exposures in developing countries such as to biomass fuels, peri-urban sprawl and inadequate water and sanitation warrant further consideration. Three African studies point to an urban environment as an important risk factor in developing countries. ${ }^{13-15}$ Urban asthma prevalence ranged from $4 \%$ to $23 \%$ in these studies, and the increase in odds from rural to urban environments ranged between 1.5 and 4 . These rates of asthma are in agreement with the region's results in the International Study of Asthma and Allergies in Childhood (ISAAC). ${ }^{1}$ Peru is reported to have one of the highest prevalences of asthma worldwide. ${ }^{1}$ ISAAC reported that $48 \%$ of adolescent children had ever wheezed and $26 \%$ had experienced wheezing within the previous year. A study in a Lima shanty town 
reported that $21 \%$ of children ever had asthma-related symptoms, and $23 \%$ showed a decrease in forced expiratory volume in $1 \mathrm{~s}\left(\mathrm{FEV}_{1}\right)$ postexercise. ${ }^{16}$ However, these studies were conducted in urban areas of Lima, where one-third of the population lives. There remains limited information on asthma in other regions of Peru or on risk factors driving this high burden of disease in Lima. We hypothesised that children living in a peri-urban setting would have a higher risk of asthma symptoms, allergy and airways inflammation than their rural counterparts.

\section{METHODS}

We provide an abbreviated description of our data collection methods. Additional detail is provided in an online supplement.

\section{Study setting}

We conducted our study in two coastal regions of Peru. Pampas de San Juan de Miraflores is a peri-urban shanty town in Lima with high population density centred on a heavily trafficked avenue. Tumbes is located in northern Peru near the Ecuador border and has little traffic and migration. We conducted our study in a cluster of 23 rural villages outside Tumbes city.

\section{Study subjects}

In Lima, we invited an age- and sex-stratified sample of adolescents $13-15$ years of age to participate. In Tumbes, we invited all 13- to 15-year-old adolescents in the above 23 villages. Inclusion and exclusion criteria are detailed in the online supplement.

\section{Study design}

We carried out home visits to enrol participants, administer the survey and perform physical testing. During the first visit, we asked about asthma and allergy symptoms using a validated questionnaire, ${ }^{17}$ asthma medications use, biomass fuel exposures and sociodemographics.

We conducted physical testing during a second visit. After measuring height and weight, we conducted spirometry presalbutamol and postsalbutamol according to standard guidelines. ${ }^{18}$ We measured exhaled nitric oxide (eNO) levels in parts per billion ( $\mathrm{ppb}$ ) and applied allergy skin tests for cockroach, dust mite mix, cat hair, dog epithelium, mouse epithelium and mixed moulds. We measured approximate $\mathrm{PM}_{2.5}$ concentrations $\left(\mu \mathrm{g} / \mathrm{m}^{3}\right)$ for $48 \mathrm{~h}$ using a portable nephelometer in a random subset of 100 households in Lima and 70 in Tumbes. We obtained outdoor PM data in Lima from DIGESA (http://www.digesa.sld.pe).

This study was approved by the Institutional Review Boards of the Johns Hopkins Bloomberg School of Public Health in Baltimore, USA, and AB PRISMA in Lima, Peru.

\section{Definitions}

We defined current asthma symptoms as wheezing or asthma medication use in the past year; atopy as a positive test to one or more skin test allergens; and reversibility as a $\geq 12 \%$ increase in $\mathrm{FEV}_{1}$ from preslabutamol to postsalbutamol. ${ }^{18}$ We graded asthma severity as per National Asthma Education Prevention Program guidelines. ${ }^{19}$

\section{Biostatistical methods}

We used standard statistical methods for the calculation of ORs and $\chi^{2}$ tests. We used logistic regression analysis to model the effect of multiple variables on the risk of asthma. We conducted analyses in R (http://www.r-project.org) and STATA 10. These methods are discussed in detail in the online supplement.

\section{RESULTS}

\section{Baseline characteristics}

Of 1851 adolescents identified from census data, we enrolled $1441(78 \%)$ during the first visit (figure 1). Seven hundred and twenty-five adolescents in Lima and 716 in Tumbes responded to our survey. Of those enrolled, 545 (75\%) in Lima and 614 (86\%) in Tumbes completed all aspects of physical testing. A total of 625 (86\%) participants in Lima and 649 (91\%) in Tumbes completed spirometry. There were no important differences in the distributions of sex or age by site (table 1). Body mass index (BMI) was greater in Lima than in Tumbes. Girls were taller in Tumbes than in Lima. Household incomes were lower in Tumbes than in Lima, as almost threefold more households reported total earnings of <US\$175 per month. Fewer households in Tumbes had private sanitation facilities $(27 \%$ vs $92 \%$, p < 0.001$)$.

Six hundred and ninety-eight (96\%) of the Lima adolescent participants had lived in Lima since birth, and $>99 \%$ had lived in the study community for $\geq 5$ years. A total of 661 (92\%) of the Tumbes adolescent participants had lived in Tumbes since birth, and $>99 \%$ have lived in the study community for $\geq 5$ years. Immigration, however, was common among parents of Lima adolescents. Of the Lima participants, 556 (77\%) had at least one parent that had emigrated from the highlands. In contrast, 564 (79\%) of the Tumbes participants had both parents who were born in Tumbes. A greater proportion of peri-urban participants reported spending at least $11 \mathrm{~h}$ a day at home than did their rural counterparts $(70 \%$ vs $60 \%$; $<0.001)$.

\section{Asthma symptoms}

All indicators of asthma symptoms were 2-3 times greater in Lima (table 2). The onset of asthma symptoms occurred at an earlier age in Lima. There were no differences in lifetime or current asthma symptoms or age of onset between boys and girls at either site (all $p \geq 0.12$ ). The most common precipitants of asthma symptoms were upper respiratory infections and exercise. There were no differences in asthma severity between sites (table 3). Approximately $50 \%$ of those with asthma were mild intermittent (table 3). A greater proportion of participants in Tumbes with asthma symptoms required emergency visits to hospitals or health centres, and fewer used inhaled

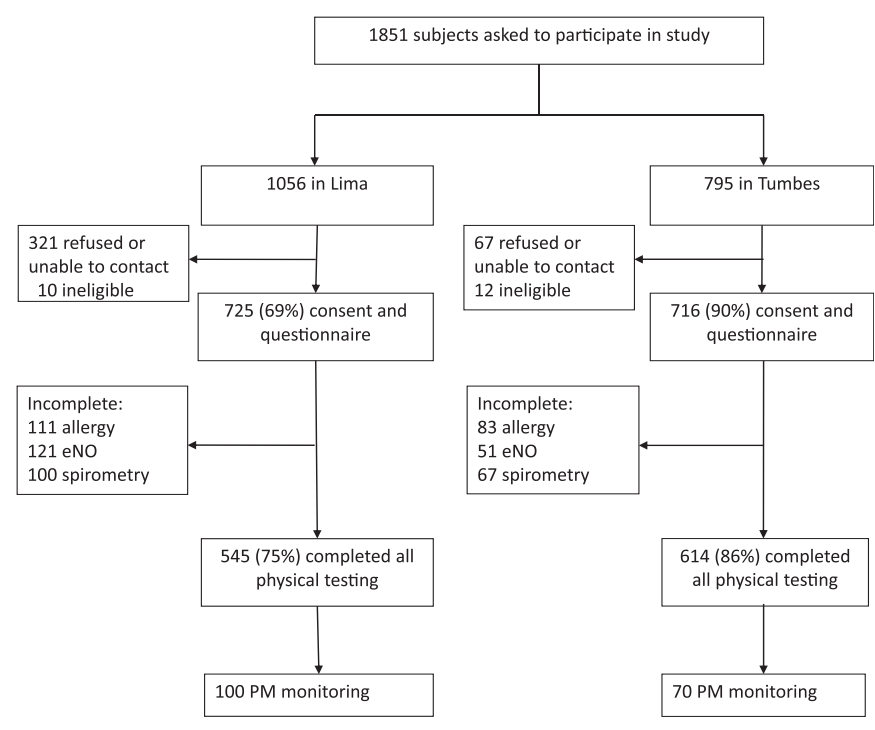

Figure 1 Flow diagram of recruitment, questionnaires and procedures in Lima and Tumbes, Peru; 2009-2010. eNO, exhaled nitric oxide; PM, particulate matter. 
Table 1 Comparison of personal characteristics, sociodemographics and exposures of adolescents aged $13-15$ in urban Lima and rural Tumbes; Peru 2009-2010

\begin{tabular}{|c|c|c|c|}
\hline & Lima & Tumbes & p Value \\
\hline No. of participants & 725 & 716 & \\
\hline No. of males (\%) & $355(49 \%)$ & $387(54 \%)$ & 0.06 \\
\hline Mean age in years (SD) & $14.9(0.9)$ & $14.9(0.9)$ & 1.00 \\
\hline Born in site & $696(96 \%)$ & $659(92 \%)$ & 0.002 \\
\hline Both parents born in site & $84(11.6 \%)$ & $564(78.8 \%)$ & $<0.001$ \\
\hline$\geq 1$ parent from highlands & $556(76.7 \%)$ & $20(2.8 \%)$ & $<0.001$ \\
\hline$\geq 1$ parent from rainforest & $17(2.3 \%)$ & $3(0.4 \%)$ & $<0.001$ \\
\hline Income $<175$ US\$/month & $181(25 \%)$ & $451(63 \%)$ & $<0.001$ \\
\hline Electricity 24 h/day & $722(100 \%)$ & $612(85 \%)$ & $<0.001$ \\
\hline Water 24 h/day & $668(92 \%)$ & $40(6 \%)$ & $<0.001$ \\
\hline Concrete as predominant floor material & $272(37.5 \%)$ & $398(55.9 \%)$ & $<0.001$ \\
\hline Propane gas as main fuel for cooking & $705(97.2 \%)$ & $609(85.1 \%)$ & $<0.001$ \\
\hline Regular use of wood-burning stoves & $72(8.6 \%)$ & $301(42.0 \%)$ & $<0.001$ \\
\hline Mean number of people per house (SD) & $5.7(1.9)$ & $5.1(1.6)$ & $<0.001$ \\
\hline Households with $\geq 6$ residents $(\%)$ & $355(49 \%)$ & $212(30 \%)$ & $<0.001$ \\
\hline Mean no. of rooms per house (SD) & $4.9(1.8)$ & $4.9(1.2)$ & 1.00 \\
\hline Time spent inside house & & & $<0.001$ \\
\hline $0-6 \mathrm{~h}$ per day & $20(2.8 \%)$ & $14(2.0 \%)$ & \\
\hline $7-10 \mathrm{~h}$ per day & $198(27.3 \%)$ & $271(37.8 \%)$ & \\
\hline $11-15 \mathrm{~h}$ per day & $507(69.9 \%)$ & $428(59.8 \%)$ & \\
\hline$\geq 15 \mathrm{~h}$ per day & $0(0 \%)$ & $3(0.4 \%)$ & \\
\hline Sanitation facilities in home & & & $<0.001$ \\
\hline Private & $668(92.1 \%)$ & $197(27.2 \%)$ & \\
\hline Latrine & $0(0.0 \%)$ & $170(23.7 \%)$ & \\
\hline Blind hole & $32(4.4 \%)$ & $212(27.8 \%)$ & \\
\hline Open field & $0(0.0 \%)$ & $113(15.8 \%)$ & \\
\hline Household owns car & $95(13.1 \%)$ & $70(9.7 \%)$ & 0.06 \\
\hline Household owns land line telephone & $446(61.5 \%)$ & $74(10.3 \%)$ & $<0.001$ \\
\hline Household owns cellular telephone & $628(86.6 \%)$ & $658(91.9 \%)$ & 0.002 \\
\hline Mean paternal education in years (SD) & $9.8(3.1)$ & $8.5(4.2)$ & $<0.001$ \\
\hline Mean maternal education in years (SD) & $8.2(3.7)$ & $8.2(4.1)$ & $<0.001$ \\
\hline Height $(\mathrm{cm})^{*}$ & $(n=651)$ & $(n=661)$ & \\
\hline Boys, mean (SD, Z-score) & $162.0(7.4) ; z=1.0$ & $163.1(8.3) ; z=0.9$ & 0.07 \\
\hline Girls, mean (SD, Z-score) & $152.8(5.5) ; z=1.5$ & $155.1(5.7) ; z=1.0$ & $<0.001$ \\
\hline Weight $(\mathrm{kg})$ & $(n=651)$ & $(\mathrm{n}=661)$ & \\
\hline Boys, mean (SD) & $56.5(11.2)$ & $53.5(10.2)$ & $<0.001$ \\
\hline Girls, mean (SD) & $52.1(9.4)$ & $51.1(8.1)$ & 0.15 \\
\hline Body mass index* & $(n=651)$ & $(n=661)$ & \\
\hline Boys, mean (SD, percentile) & $21.4(3.3) ; 65$ th & $20.0(2.8) ; 50$ th & 0.001 \\
\hline Girls, mean (SD, percentile) & $22.3(3.5) ; 75$ th & 21.2 (3.1);60th & $<0.001$ \\
\hline Haematocrit & $(n=552)$ & $(n=579)$ & \\
\hline Boys, mean (SD) & $44.9(3.1)$ & $42.6(2.8)$ & $<0.001$ \\
\hline Girls, mean (SD) & $41.0(2.9)$ & $39.2(2.4)$ & $<0.001$ \\
\hline
\end{tabular}

*Z-scores and percentiles as per 2007 WHO reference.

corticosteroids or long-acting $\beta$-agonists for asthma control compared with those in Lima.

Adolescents with current asthma symptoms were equally likely to have a lifetime history of rhinitis across sites (table 3). Among those with asthma, the rate of atopy was greater in Lima than in Tumbes ( $77 \%$ vs $56 \%$, respectively); however, this increase only trended towards significance $(p=0.09)$. Adolescents in Lima without current asthma symptoms had a greater prevalence of lifetime rhinitis or atopy than adolescents in Tumbes. Overall, there was a higher prevalence of eczema and a greater number of positive allergen skin tests in Lima than in Tumbes, regardless of asthma symptoms. Rhinitis in the past 12 months, eczema in the past 12 months, atopy and being overweight (BMI >25) were all predictors of current asthma symptoms in Lima in both the unadjusted and multivariable analyses (table 4). In Tumbes, where we had fewer participants with current asthma symptoms $(n=22)$, we identified rhinitis in the past 12 months as the only significant predictor of current asthma symptoms. When we pooled data from both sites, rhinitis in the past 12 months, atopy and being overweight remained important predictors of current asthma symptoms (table 4). The peri-urban environment of Lima was associated with a 2.6-fold greater odds (OR 2.6, 95\% CI 1.3 to 5.3) of current asthma after controlling for atopy, allergy symptoms, environmental exposures, household size, sanitation and sociodemographics. We did not find interactions between urbanisation status and: atopy $(p=0.38)$, rhinitis $(p=0.14)$ or being overweight $(p=0.67)$.

\section{Allergic symptoms}

Self-reported symptoms of allergic rhinitis were almost twice as prevalent among participants in Lima as among those in Tumbes 
Table 2 Differences in asthma, allergic symptoms and atopy between Lima and Tumbes; Peru 2009-2010

\begin{tabular}{lccc}
\hline & $\begin{array}{l}\text { Lima } \\
(\mathbf{n = 7 2 5})\end{array}$ & $\begin{array}{l}\text { Tumbes } \\
(\mathbf{n = 7 1 6 )}\end{array}$ & $\mathbf{p ~ V a l u e}$ \\
\hline Asthma & & & \\
$\quad$ Lifetime wheezing & $157(21.7 \%)$ & $68(9.5 \%)$ & $<0.001$ \\
Lifetime exercise-induced wheezing & $58(8 \%)$ & $16(2.2 \%)$ & $<0.001$ \\
Lifetime night-time, non-productive cough & $62(8.6 \%)$ & $30(4.2 \%)$ & $<0.001$ \\
Lifetime physician diagnosis of asthma & $94(13 \%)$ & $16(2.2 \%)$ & $<0.001$ \\
Age at onset of symptoms, years & $7.1(4.6)$ & $8.4(4.1)$ & 0.05 \\
& & & \\
Current asthma & $84(11.6 \%)$ & $22(3.1 \%)$ & $<0.001$ \\
$\quad$ Wheezing in the past 12 months & $73(10.1 \%)$ & $20(2.8 \%)$ & $<0.001$ \\
$\quad$ Use of medications for asthma & $37(5.1 \%)$ & $11(1.5 \%)$ & $<0.001$ \\
$\quad$ control in the past 12 months & & & \\
& & & \\
Rhinitis & $189(26.1 \%)$ & $98(13.7 \%)$ & $<0.001$ \\
Lifetime rhinitis symptoms & $166(22.9 \%)$ & $86(12.0 \%)$ & $<0.001$ \\
Rhinitis symptoms in the past 12 months & $25(3.4 \%)$ & $9(1.3 \%)$ & 0.01 \\
Physician diagnosis of rhinitis & $150(20.7 \%)$ & $28(3.9 \%)$ & $<0.001$ \\
Parental rhinitis & & & \\
& & & \\
Eczema & $113(15.6 \%)$ & $7(1.0 \%)$ & $<0.001$ \\
Lifetime eczema symptoms & $90(12.4 \%)$ & $3(0.4 \%)$ & $<0.001$ \\
Eczema symptoms in the past 12 months & $44(6.1 \%)$ & $10(1.4 \%)$ & $<0.001$ \\
Physician diagnosis of eczema & $112(15.4 \%)$ & $19(2.7 \%)$ & $<0.001$ \\
Parental eczema & & & \\
\hline & & &
\end{tabular}

(table 2). A physician diagnosis of rhinitis was exceptionally rare at either site despite a high proportion of symptom reporting among study participants. Parental rhinitis was fivefold higher in Lima, and in both sites it was a risk factor for rhinitis among offspring (OR 3.0, 95\% CI 2.2 to 4.2). Eczema was more prevalent in Lima than in Tumbes (table 2). As with rhinitis, a physician diagnosis of eczema was low despite high symptom rates. Atopy was significantly higher in Lima than in Tumbes $(56 \%$ vs $38 \%, p<0.001)$. The odds of atopy were not increased by having at least six residents in the household, a measure we used as a surrogate for sibling number in either Tumbes (OR 1.3, $95 \%$ CI 0.9 to 1.9 ) or Lima (OR $1.0,95 \%$ CI 0.8 to 1.4 ).

\section{Spirometry and postbronchodilator reversibility}

Six hundred and twenty-five (86\%) participants in Lima and 649 (91\%) in Tumbes completed spirometry according to standard quality criteria. FEVs were significantly greater in Lima than in Tumbes (table 5). These differences remained even after controlling for age and height within each sex group (all $\mathrm{p}<0.001)$. $\mathrm{FEV}_{1}$ /forced vital capacity $(\mathrm{FVC}$ ) values were also lower in Lima than in Tumbes (eFigure 1 (see online)). Reversibility was higher in Lima, but it did not achieve statistical significance (table 5).

\section{Airways inflammation}

Mean eNO levels were significantly higher in Lima than in Tumbes (21.9 vs 17.6 ppb; p <0.001). Current asthma symptoms, rhinitis in the past 12 months and atopy increased mean eNO levels at both sites (all p <0.001). eNO measurements conducted in the spring were also higher than measurements conducted in the autumn at both sites $(p \leq 0.05)$. Otherwise, there was considerable heterogeneity in the effect of multiple predictors on eNO across sites (eTable 1 (see online)). After adjusting for asthma and atopy in multivariable regression, we found that there was no difference in eNO by site $(p=0.47)$. In multivariable regression, there was a multiplicative interaction
Table 3 Asthma severity, burden and relationship with atopy among those with current asthma in Lima and Tumbes; Peru 2009-2010

\begin{tabular}{|c|c|c|c|}
\hline Asthma & $\begin{array}{l}\text { Lima } \\
(\mathrm{n}=84)\end{array}$ & $\begin{array}{l}\text { Tumbes } \\
(\mathrm{n}=22)\end{array}$ & p Value \\
\hline Severity & & & 0.44 \\
\hline Mild intermittent & $44(52.4 \%)$ & $12(54.5 \%)$ & \\
\hline Mild persistent & $18(21.4 \%)$ & $4(18.2 \%)$ & \\
\hline Moderate persistent & $18(21.4 \%)$ & $3(13.6 \%)$ & \\
\hline Severe persistent & $4(4.8 \%)$ & $3(13.6 \%)$ & \\
\hline $\begin{array}{l}\text { Any emergency visits in the past } \\
12 \text { months }\end{array}$ & $24(28.6 \%)$ & $10(45.5 \%)$ & 0.21 \\
\hline Rescue medication use & $34(40.5 \%)$ & $10(45.5 \%)$ & 0.86 \\
\hline Never & $49(58.3 \%)$ & $12(54.5 \%)$ & \\
\hline$<1$ use per week & $6(7.1 \%)$ & $5(22.3 \%)$ & \\
\hline $1-3$ uses per week & $14(16.7 \%)$ & $3(13.6 \%)$ & \\
\hline$>3$ uses per week & $14(16.7 \%)$ & $2(9.1 \%)$ & \\
\hline Any medication use in the past 12 months & $29(31.1 \%)$ & $11(50.0 \%)$ & 0.28 \\
\hline Short-acting bronchodilator & $28(33.3 \%)$ & $10(45.5 \%)$ & 0.42 \\
\hline Long-acting bronchodilator & $0(0 \%)$ & $0(0 \%)$ & 1 \\
\hline Inhaled corticosteroid & $3(3.6 \%)$ & $0(0 \%)$ & 1 \\
\hline Oral corticosteroid & $21(25.0 \%)$ & $2(9.1 \%)$ & 0.15 \\
\hline Allergy and asthma & $(n=614)$ & $(n=630)$ & \\
\hline Overall skin test positivity & $342(55.7 \%)$ & $242(38.4 \%)$ & $<0.001$ \\
\hline Allergy in asthmatics & $(n=84)$ & $(\mathrm{n}=22)$ & \\
\hline Lifetime rhinitis symptoms & $45(53.6 \%)$ & $13(59.1 \%)$ & 0.83 \\
\hline Lifetime eczema symptoms & $22(26.2 \%)$ & $1(4.5 \%)$ & 0.04 \\
\hline Skin test positivity & $(n=74)$ & $(n=20)$ & \\
\hline$\geq 1$ & $57(77.0 \%)$ & $11(55.9 \%)$ & 0.09 \\
\hline$\geq 2$ & $46(62.2 \%)$ & $7(35.0 \%)$ & 0.06 \\
\hline$\geq 3$ & $30(40.5 \%)$ & $4(20.0 \%)$ & 0.12 \\
\hline Allergy in non-asthmatics & $(n=641)$ & $(n=694)$ & \\
\hline Lifetime rhinitis symptoms & $151(23.2 \%)$ & $88(12.7 \%)$ & $<0.001$ \\
\hline Lifetime eczema symptoms & $107(16.4 \%)$ & $15(2.2 \%)$ & $<0.001$ \\
\hline Skin test positivity & $(n=540)$ & $(n=610)$ & \\
\hline$\geq 1$ & $285(52.8 \%)$ & $231(37.9 \%)$ & $<0.001$ \\
\hline$\geq 2$ & $188(34.8 \%)$ & 119 (19.5\%) & $<0.001$ \\
\hline$\geq 3$ & $111(21.1 \%)$ & $41(6.7 \%)$ & $<0.001$ \\
\hline
\end{tabular}

between the current asthma symptoms and atopy on eNO levels (table 6; $p=0.04$ for Lima and $p<0.001$ for Tumbes).

\section{Household exposures}

The primary source of cooking fuel was propane gas at both sites (table 1). A greater proportion of households used wood-burning stoves for cooking on a daily or semi-daily basis in Tumbes than in Lima ( $42 \%$ vs $8.6 \%$; $<0.001$ ). While propane gas stoves were used exclusively indoors, wood-burning stoves were generally used outside of the house (data not shown). Tumbes adolescents had higher rates of secondhand smoking exposure versus Lima adolescents $(20.3 \%$ vs $12.8 \%$, respectively; $p<0.001)$. A greater proportion of adolescents reported ever smoking in Lima than in Tumbes $(7.4 \%$ vs $2.2 \%$, respectively; $\mathrm{p}<0.001)$.

Median concentrations of indoor PM in Lima were $\sim 2.4$-fold higher than those in Tumbes $\left(31 \mu \mathrm{g} / \mathrm{m}^{3}\right.$ vs $13 \mu \mathrm{g} / \mathrm{m}^{3} ; \mathrm{p}<0.001$; figure 2). We speculate that indoor pollution levels probably reflect outdoor pollution levels at both sites for two reasons. First, most houses regularly left open doors $73 \%$ in Lima and $97 \%$ in Tumbes) or windows (75\% in Lima and $94 \%$ in Tumbes) during the daytime year-round, and on average there were two 
Table 4 Multivariable analysis on the odds of current asthma symptoms stratified by study site; Peru, 2009-2010

\begin{tabular}{|c|c|c|c|c|c|c|c|c|c|c|}
\hline \multirow[b]{2}{*}{ Exposure } & \multicolumn{4}{|c|}{ Lima $(n=725)$} & \multicolumn{4}{|c|}{ Tumbes $(n=716)$} & \multirow[b]{2}{*}{$\begin{array}{l}\text { Mantel- } \\
\text { Haenszel } \\
\text { OR }(95 \% \mathrm{CI})\end{array}$} & \multirow[b]{2}{*}{$\begin{array}{l}\text { Pooled } \\
\text { multivariable } \\
\text { OR (95\% CI) }\end{array}$} \\
\hline & $\begin{array}{l}\text { \% Asthma } \\
\text { in unex- } \\
\text { posed }\end{array}$ & $\begin{array}{l}\text { \% Asthma } \\
\text { in ex- } \\
\text { posed }\end{array}$ & $\begin{array}{l}\text { Unadjusted } \\
\text { OR (95\% CI) }\end{array}$ & $\begin{array}{l}\text { Multivariable } \\
\text { OR (95\% CI) }\end{array}$ & $\begin{array}{l}\text { \% Asthma } \\
\text { in unex- } \\
\text { posed }\end{array}$ & $\begin{array}{l}\% \text { Asthma } \\
\text { in exposed }\end{array}$ & $\begin{array}{l}\text { Unadjusted } \\
\text { OR (95\% CI) }\end{array}$ & $\begin{array}{l}\text { Multivariable } \\
\text { OR (95\% CI) }\end{array}$ & & \\
\hline $\begin{array}{l}\text { Rhinitis in past } \\
12 \text { months }\end{array}$ & $7.3 \%$ & $25.9 \%$ & 4.4 (2.7 to 7.3$)$ & 3.7 (2.2 to 6.5$)$ & $1.4 \%$ & $15.1 \%$ & $\begin{array}{l}12.1 \\
(5.0 \text { to } 30.7)\end{array}$ & $\begin{array}{l}11.4 \\
(3.9 \text { to } 33.1)\end{array}$ & 5.3 (3.5 to 8.1$)$ & 4.8 (3.0 to 7.6$)$ \\
\hline $\begin{array}{l}\text { Eczema in past } \\
12 \text { months }\end{array}$ & $10.1 \%$ & $21.1 \%$ & 2.4 (1.3 to 4.3$)$ & $2.1(1.1$ to 4.1$)$ & $3.1 \%$ & $0.0 \%$ & & & & \\
\hline Atopy & $6.3 \%$ & $16.7 \%$ & $3.0(1.7$ to 5.6$)$ & $2.5(1.4$ to 4.5$)$ & $2.3 \%$ & $4.5 \%$ & $2.0(0.7$ to 5.6$)$ & $1.8(0.7$ to 4.8$)$ & 2.7 (1.7 to 4.4$)$ & 2.2 (1.3 to 3.7$)$ \\
\hline BMI $\left(\mathrm{kg} / \mathrm{m}^{2}\right)>25$ & $10.4 \%$ & $21.7 \%$ & $2.4(1.3$ to 4.2$)$ & $2.5(1.4$ to 4.5$)$ & $2.8 \%$ & $7.0 \%$ & $2.6(0.6$ to 8.5$)$ & $1.3(0.3$ to 5.5$)$ & $2.4(1.5$ to 3.9$)$ & 2.2 (1.3 to 3.8$)$ \\
\hline $\begin{array}{l}\text { Income } \\
<\text { US } \$ 175 / \text { month }\end{array}$ & $10.9 \%$ & $13.6 \%$ & $1.3(0.7$ to 2.2$)$ & $1.4(0.7$ to 2.5$)$ & $4.9 \%$ & $2.0 \%$ & $0.4(0.1$ to 1.0$)$ & $0.3(0.1$ to 0.9$)$ & $0.9(0.6$ to 1.5$)$ & $0.9(0.5$ to 1.6$)$ \\
\hline Concrete floor & $11.9 \%$ & $11.0 \%$ & $0.9(0.5$ to 1.5$)$ & $0.7(0.4$ to 1.2$)$ & $2.2 \%$ & $3.8 \%$ & $1.7(0.7$ to 5.1$)$ & $1.6(0.6$ to 4.4$)$ & $1.1(0.7$ to 1.6$)$ & 0.8 (0.5 to 1.3$)$ \\
\hline $6+$ people/house & $10.8 \%$ & $12.4 \%$ & $1.2(0.7$ to 1.9$)$ & $1.1(0.6$ to 1.9$)$ & $2.5 \%$ & $4.2 \%$ & $1.7(0.6$ to 4.3$)$ & $1.2(0.4$ to 3.5$)$ & $1.3(0.8$ to 1.9$)$ & $1.1(0.7$ to 1.8$)$ \\
\hline $\begin{array}{l}\text { Maternal primary } \\
\text { schooling }\end{array}$ & $19.0 \%$ & $10.0 \%$ & 0.7 (0.4 to 1.3$)$ & $0.9(0.5$ to 1.7$)$ & $1.4 \%$ & $3.7 \%$ & 2.7 (0.8 to 14.3 ) & $2.2(0.6$ to 8.5$)$ & $0.9(0.6$ to 1.5$)$ & 1.1 (0.6 to 1.9$)$ \\
\hline Wood stove & $11.3 \%$ & $14.5 \%$ & $1.3(0.6$ to 2.9$)$ & $1.7(0.7$ to 4.0$)$ & $3.1 \%$ & $3.1 \%$ & $1.0(0.4$ to 2.4$)$ & $2.3(0.7$ to 7.1$)$ & $1.1(0.6$ to 2.0$)$ & $1.6(0.8$ to 3.1$)$ \\
\hline Personal smoke & $12.0 \%$ & $15.6 \%$ & $1.3(0.5$ to 3.2$)$ & $1.3(0.5$ to 3.5$)$ & $3.6 \%$ & $0.0 \%$ & & & & \\
\hline Secondhand smoke & $12.1 \%$ & $9.2 \%$ & $0.7(0.3-1.5)$ & $0.7(0.3$ to 1.4$)$ & $3.8 \%$ & $0.6 \%$ & & & & \\
\hline Private sanitation & $8.8 \%$ & $11.8 \%$ & $1.4(0.5$ to 4.6$)$ & $1.9(0.6$ to 6.2$)$ & $2.5 \%$ & $4.5 \%$ & $1.8(0.7$ to 4.7$)$ & $0.6(0.2$ to 1.9$)$ & $1.6(0.8$ to 3.1$)$ & $1.3(0.6$ to 2.8$)$ \\
\hline $\begin{array}{l}1+\text { parent from } \\
\text { highlands }\end{array}$ & $11.8 \%$ & $11.5 \%$ & $1.0(0.6$ to 1.7$)$ & $0.9(0.5$ to 1.8$)$ & $3.6 \%$ & $0.0 \%$ & & & & \\
\hline $\begin{array}{l}\text { Peri-urban } \\
\text { environment }\end{array}$ & & & & & & & & & & 2.6 (1.3 to 5.2 ) \\
\hline
\end{tabular}

All variables included in each of the multivariable models are listed under the exposure column.

BMI, body mass index.

windows and 1.4 doors left open at all times. Secondly, average 24 h outdoor $\mathrm{PM}_{2.5}$ concentrations in Lima were similar to indoor levels at $38 \mu \mathrm{g} / \mathrm{m}^{3}$ for 2009. Outdoor $\mathrm{PM}_{2.5}$ concentrations were not available in Tumbes.

\section{DISCUSSION}

Adolescents living in peri-urban Lima were at a much higher risk of having asthma and allergy symptoms than their rural counterparts in Tumbes. Specifically, asthma symptoms were

Table 5 Comparison of forced expiratory volumes before and after bronchodilators in Lima and Tumbes; Peru, 2009-2010

\begin{tabular}{|c|c|c|c|}
\hline & Lima $(n=625)$ & Tumbes $(n=649)$ & p Value \\
\hline \multicolumn{4}{|l|}{ Sample size } \\
\hline Boys & 311 & 348 & \\
\hline Girls & 314 & 301 & \\
\hline \multicolumn{4}{|l|}{ Mean pre-FVC in litres (SD) } \\
\hline Boys & $4.36(0.7)$ & $3.82(0.7)$ & $<0.001$ \\
\hline$\%$ Predicted (SD)* & $110 \%(13 \%)$ & $94.2 \%(11 \%)$ & $<0.001$ \\
\hline Girls & $3.46(0.5)$ & $3.08(0.4)$ & $<0.001$ \\
\hline$\%$ Predicted $(\mathrm{SD})^{*}$ & $109 \%(13 \%)$ & $93.7 \%(12 \%)$ & $<0.001$ \\
\hline \multicolumn{4}{|c|}{ Mean pre- $\mathrm{FEV}_{1}$ in litres $(\mathrm{SD})$} \\
\hline Boys & $3.83(0.6)$ & $3.44(0.6)$ & $<0.001$ \\
\hline$\%$ Predicted (SD)* & $111 \%(13 \%)$ & $97 \%(12 \%)$ & $<0.001$ \\
\hline Girls & $3.08(0.4)$ & $2.82(0.4)$ & $<0.001$ \\
\hline$\%$ Predicted (SD)* & $109 \%(12 \%)$ & $97 \%(111 \%)$ & $<0.001$ \\
\hline \multicolumn{4}{|l|}{ Mean pre-FEV $/$ FVC \% (SD) } \\
\hline Boys & $88 \%(6 \%)$ & $90 \%(6 \%)$ & $<0.001$ \\
\hline Girls & $89 \%(6 \%)$ & $92 \%(6 \%)$ & $<0.001$ \\
\hline Reversibility, $\mathrm{n}(\%)$ & $24(3.8 \%)$ & $15(2.3 \%)$ & 0.16 \\
\hline Boys & $11(3.5 \%)$ & $9(2.6 \%)$ & 0.63 \\
\hline Girls & $13(4.1 \%)$ & $6(2.0 \%)$ & 0.14 \\
\hline
\end{tabular}

2-3 times greater in Lima alongside a twofold increase in allergic symptoms, a $50 \%$ increase in atopy and a 15 -fold increase in eczema. Adolescents in Lima also had a lower FEV 1 /FVC than did those in Tumbes. While postbronchodilator reversibility was also more common in Lima, this increase did not achieve statistical significance. Higher rates of asthma symptoms and atopy in Lima were associated with greater airways inflammation. Adolescents in Lima were exposed to higher levels of indoor air pollution, were more likely to smoke, had a greater mean BMI and were more likely to live in households with adequate sanitation facilities than adolescents in Tumbes. Thus, urbanisation is linked to several factors that may help explain why we would expect to see more asthma and atopy in Lima than in Tumbes.

It is well recognised that urbanisation is an important risk factor for asthma in both developed and developing countries. ${ }^{9}{ }^{13-15}$ Most of the in-depth studies on urbanisation and asthma in developing countries have been conducted in Africa. ${ }^{21}$

Table 6 Exhaled nitric oxide levels stratified by current asthma symptoms and atopy in Lima and Tumbes; Peru, 2009-2010

\begin{tabular}{lllr}
\hline & Mean & SD & N \\
\hline Overall (n=1199) & 19.5 & 22.2 & 1199 \\
Asthma, atopy & 52.6 & 52.3 & 64 \\
Asthma, no atopy & 25.5 & 29.9 & 25 \\
No asthma, atopy & 22.6 & 21.9 & 492 \\
No asthma, no atopy & 13.8 & 12.0 & 618 \\
Tumbes (n=625) & 17.6 & 19.0 & 625 \\
Asthma, atopy & 33.0 & 19.9 & 11 \\
Asthma, no atopy & 48.3 & 40.5 & 9 \\
No asthma, atopy & 22.9 & 23.7 & 229 \\
No asthma, no atopy & 13.1 & 13.1 & 376 \\
Lima (n=574) & 21.7 & 25.2 & 574 \\
Asthma, atopy & 56.7 & 56.0 & 53 \\
Asthma, no atopy & 12.7 & 8.1 & 16 \\
No asthma, atopy & 22.3 & 20.2 & 263 \\
No asthma, no atopy & 14.4 & 10.2 & 242 \\
\hline
\end{tabular}




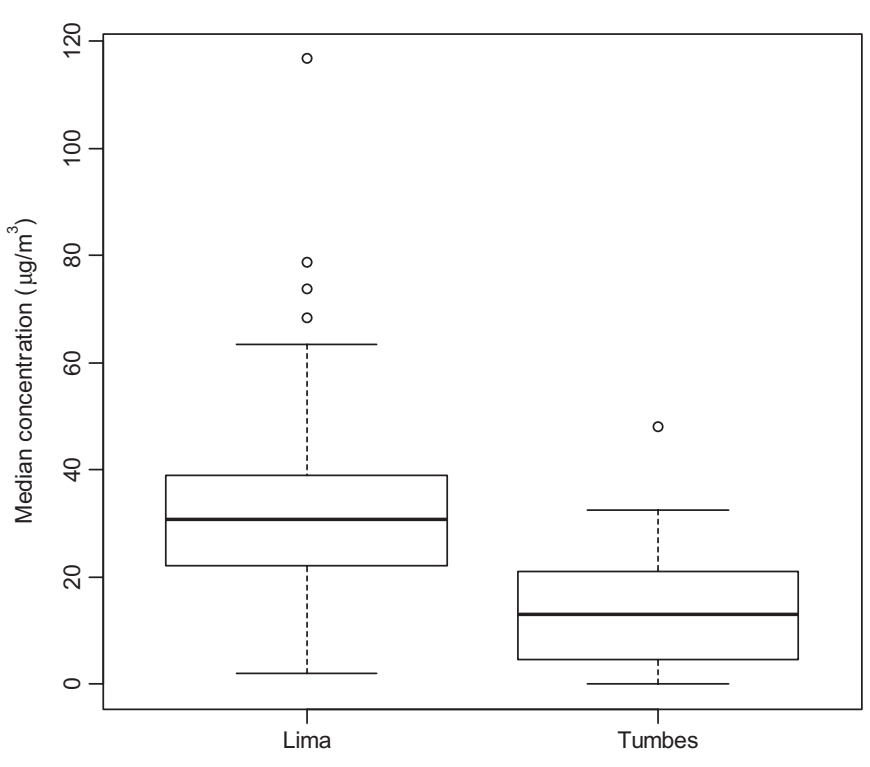

Figure 2 Boxplots of median particulate matter concentrations (approximate $\mathrm{PM}_{2.5}$ ) in Lima and Tumbes; Peru 2009-2010.

A recent study conducted in Ghana found that urban poor adolescents had similar rates of exercise-induced bronchoconstriction to their rural counterparts, whereas wealthy urban adolescents had much higher rates. ${ }^{22}$ In our study, unlike the study in Ghana, urban poor adolescents had a two- to three-fold greater risk of asthma symptoms. Meanwhile, there is limited published information on how urbanisation affects asthma symptoms or quantitative asthma phenotypes in Latin America and what unique exposures may drive differences in the prevalence of asthma across varying degrees of urbanisation. One study performed in Costa Rica found that sensitisation to Ascaris lumbricoides was associated with reductions in $\mathrm{FEV}_{1}$ and $\mathrm{FEV}_{1} / \mathrm{FVC}$, increased airway responsiveness and a greater number of asthma hospitalisations. ${ }^{23}$ Other studies have shown that the prevalence of asthma symptoms increases among Peruvian children living in areas of high traffic density, ${ }^{24}$ and that higher levels of air pollutants were associated with higher rates of emergency room asthma visits in Mexico City. ${ }^{25}$ In addition, the contributions of biomass fuels and indoor air pollution to asthma risk have not been carefully characterised in urban versus rural studies. In our study, we collected detailed information on biomass fuels and quantitative measurements of indoor PM. In Tumbes, nearly half of the households cooked with firewood on a daily or semi-daily basis. However, we did not observe a greater risk of asthma in adolescents who lived in households that used wood-burning stoves frequently. This may be because most wood-burning stoves in Tumbes were exclusively located outdoors. Since indoor PM concentrations were on average twice as great in Lima, outdoor biomass cooking did not appear to have a significant effect on indoor PM concentrations in Tumbes. As households in both sites had open connections to the environment year-round, we believe that these increased levels in Lima probably reflect high outdoor air pollution.

There are several risk factors that may help explain differences in asthma between our sites, such as obesity, diet and exposure to infections early in childhood. An increased BMI may be a consequence of a more sedentary lifestyle or changes in diet. In our study, overweight was a risk factor for asthma, which supports the conclusions of a recent systematic review. ${ }^{26}$ Diet has also been implicated in the development of asthma. ${ }^{27}$ Increased urbanisation can have a direct effect on changes in diet; however, we did not collect diet information. It is also possible that differences in rates of infections between Lima and Tumbes may help explain differences in asthma. Participants in Tumbes were more likely to have less access to adequate sanitation facilities that may increase their risk of infection; however, we did not have information on past history or current history of infections, nor did we test for parasitic infections. A greater sibship size is thought to be protective against asthma. We did not collect data on sibship size; however, there was no relationship between household size and either asthma or atopy. We also did not assess for airways hyper-responsiveness. Airways hyper-responsiveness is a marker of asthma, and previous studies in developing countries have shown $>20 \%$ rates of exercise-induced bronchoconstriction in urban areas. ${ }^{13} 16$

We were surprised to find that adolescents in Lima had 10-15\% larger FEVs than did those from Tumbes, accompanied by significantly larger percentage predicted values for $\mathrm{FEV}_{1}$ and FVC. We initially speculated that this difference may have been related to parental origins as they could not be explained by differences in the distributions of age, height or sex. While $>95 \%$ of adolescents from our Lima site were born in Lima, over threequarters had at least one parent that had emigrated from highaltitude rural areas. It has been previously reported that lung volumes are elevated in both native highlanders and non-native individuals living in the highlands. ${ }^{28-30}$ One possible explanation is that these children had a genetic predisposition to having greater lung volumes; however, this hypothesis needs further investigation. Despite these lung function differences, we did not see additional risk of asthma conveyed by having one or both parents from the highlands among Lima adolescents.

The peri-urban environment of Lima was associated with a 2.6-fold greater odds of current asthma after controlling for atopy, allergy symptoms, environmental exposures, household size, sanitation and sociodemographics. On the other hand, the risk of atopy only increased by $50 \%$. This suggests that the higher prevalence of asthma in the peri-urban setting cannot be explained by the increase in atopy alone; there may be several contributing factors. For example, traffic in peri-urban Lima is poorly regulated and may be associated with an increased risk of both childhood asthma ${ }^{24} 31$ and atopy. ${ }^{31}$ Heavy traffic volumes also contribute to poor air quality. Our study found that indoor air pollution was also higher in Lima; however, we only collected indoor air pollution levels in a subset of households at both study sites and the relationship between environment and asthma and how it interacts with other risk factors such as genetic predisposition needs to be further explored. A higher rate of smoking alongside a higher prevalence of allergic rhinitis in peri-urban Lima may further predispose children to asthma symptoms. ${ }^{32}$ A higher rate of smoking may also contribute to decreased effectiveness of inhaled corticosteroid therapy in asthmatics. ${ }^{33}$

While it has become clear that eNO may be less useful in the diagnosis of asthma, ${ }^{34}$ it may be helpful in identifying participants with co-morbid asthma and atopy. In our study, eNO levels in Lima were higher because there was more asthma and atopy in this population. This corroborates recent findings, ${ }^{35}$ meanwhile suggesting that atopic asthma may be more severe than non-atopic asthma or that it may even be a related but distinct process altogether.

In summary, we found that the peri-urban environment is a risk factor for asthma and atopy. As urban centres in developing countries continue to grow, governments can implement policies to curb the effects of rapid urbanisation and urban health exposures. In doing so, they will not only improve quality 
of life for their urban inhabitants, but may also help curb the emerging asthma epidemic in many developing countries.

Acknowledgements We are grateful to administrative and operations support staff at AB PRISMA in Lima, to Dr Hugo Garcia (Universidad Peruana Cayetano Heredia, Lima, Peru) and the Cysticercosis Elimination Project in Tumbes. Lincoln Diagnostics (Decatur, Illinois) and ALK-Abello (Round Rock, Texas) generously donated all skin prick atopy kits and antigens, respectively, used in this study. Aerocrine (New Providence, New Jersey) provided us, at discount, materials for eNO testing.

Funding The study was supported by the Johns Hopkins Center for Global Health (Principal Investigator NNH) and the Fogarty International Center, National Institutes of Health (NIH; grant R24 TW007988). WC was supported by a Clinician Scientist Award from the Johns Hopkins University, a K99/R00 Pathway to Independence Award (K99HL096955) from the National Heart, Lung and Blood Institute, NIH and by a contract (HHSN268200900033C) with the National Heart, Lung and Blood Institute, $\mathrm{NIH}$. KCB was supported in part by the Mary Beryl Patch Turnbull Scholar Program. CLR was a Fogarty International Clinical Research Scholar during the time of the study and was further supported by Tufts University School of Medicine and by a pre-doctoral T35 Training Grant (T35Al065385) of the NIH. LMB was supported by a predoctoral T35 Training Grant (T35Al065385) of the NIH. Support for exposure measurements was provided by National Institute for Environmental Health Sciences grant numbers (ES015803). RAW was supported in part by the Dorney-Koppel Family Foundation. NNH, WC and PNB were also supported by an R01 grant from the National Institutes of Environmental Health Sciences (R01ES018845). Study sponsors played no role in the study design, data collection, data analysis, data interpretation or the decision to submit the article for publication. The opinions, results and conclusions reported in this paper are those of the authors and are independent from the funding sources. All authors had full access to all of the data (including statistical reports and tables) in the study and can take responsibility for the integrity of the data and the accuracy of the data analysis.

\section{Competing interests None.}

Ethics approval This study was conducted with the approval of the Institutional Review Boards of the Johns Hopkins Bloomberg School of Public Health in Baltimore, USA, and AB PRISMA in Lima, Peru.

Contributors All authors were involved in the study design and writing of the manuscript. CLR directly contributed to the study design, supervision of field activities in both Tumbes and Lima, and is responsible for data management and analysis, and writing of this manuscript. LMB contributed equally to the study design, administration of field work, and data management and analysis, and also contributed to the writing of the manuscript. RHG is the main investigator at the Lima site and provided technical support during the conduct of the study. KR, JMC and AG were the on-site study physicians who performed most physical testing and were extensively involved in administering field work. LC is the field work supervisor at the Lima site, and provided census data and technical support. GG is the physician supervisor for research activities at the Tumbes site, and provided census data and technical support. NNH and RAW contributed to the study design and provided technical support for the study. KCB contributed to the study design and provided logistical support for the study. PNB contributed to study design of the environmental measurements, and provided both technical support and equipment for our study. WC had ultimate oversight over the study design and administration, and was equally responsible for the analysis and writing of the manuscript.

Provenance and peer review Not commissioned; externally peer reviewed.

\section{REFERENCES}

1. Anon. Worldwide variation in prevalence of symptoms of asthma, allergic rhinoconjunctivitis, and atopic eczema: ISAAC. The International Study of Asthma and Allergies in Childhood (ISAAC) Steering Committee. Lancet 1998;351:1225-32.

2. Masoli M, Fabian D, Holt $\mathrm{S}$, et al. The global burden of asthma: executive summary of the GINA Dissemination Committee report. Allergy 2004;59:469-78.

3. Shaaban R, Zureik M, Soussan D, et al. Rhinitis and onset of asthma: a longitudinal population-based study. Lancet 2008;372:1049-57.

4. van der Hulst AE, Klip H, Brand PL. Risk of developing asthma in young children with atopic eczema: a systematic review. J Allergy Clin Immunol 2007;120:565-9.

5. Burgess JA, Dharmage SC, Byrnes GB, et al. Childhood eczema and asthma incidence and persistence: a cohort study from childhood to middle age. J Allergy Clin Immunol 2008;122:280-5.
6. Sherrill DL, Stein $\mathrm{R}$, Halonen $\mathrm{M}$, et al. Total serum IgE and its association with asthma symptoms and allergic sensitization among children. J Allergy Clin Immunol 1999;104:28-36

7. Gergen PJ, Mullally DI, Evans R 3rd. National survey of prevalence of asthma among children in the United States, 1976 to 1980. Pediatrics 1988;81:1-7.

8. Wieringa MH, Weyler JJ, Van Bastelaer FJ, et al. Higher asthma occurrence in an urban than a suburban area: role of house dust mite skin allergy. Eur Respir $J$ 1997; 10:1460-6.

9. Wong GW, Chow CM. Childhood asthma epidemiology: insights from comparative studies of rural and urban populations. Pediatr Pulmonol 2008;43:107-16.

10. Modig L, Toren K, Janson C, et al. Vehicle exhaust outside the home and onset of asthma among adults. Eur Respir J 2009;33:1261-7.

11. Hijazi N, Abalkhail B, Seaton A. Diet and childhood asthma in a society in transition a study in urban and rural Saudi Arabia. Thorax 2000;55:775-9.

12. Gao J, Gao X, Li W, et al. Observational studies on the effect of dietary antioxidants on asthma: a meta-analysis. Respirology 2008;13:528-36.

13. Yemaneberhan H, Bekele Z, Venn A, et al. Prevalence of wheeze and asthma and relation to atopy in urban and rural Ethiopia. Lancet 1997;350:85-90.

14. Ng'ang'a LW, Odhiambo JA, Mungai MW, et al. Prevalence of exercise induced bronchospasm in Kenyan school children: an urban-rural comparison. Thorax 1998; 53:919-26

15. Odhiambo JA, Ng'ang'a LW, Mungai MW, et al. Urban-rural differences in questionnaire-derived markers of asthma in Kenyan school children. Eur Respir $J$ 1998; 12:1105-12.

16. Penny ME, Murad S, Madrid SS, et al. Respiratory symptoms, asthma, exercise test spirometry, and atopy in schoolchildren from a Lima shanty town. Thorax 2001:56:607-12.

17. Mata Fernandez C, Fernandez-Benitez M, Perez Miranda M, et al. Validation of the Spanish version of the Phase III ISAAC questionnaire on asthma. J Investig Allergol Clin Immunol 2005;15:201-10.

18. Miller MR, Hankinson J, Brusasco V, et al; ATS/ERS Task Force. Standardisation of spirometry. Eur Respir J 2005;26:319-38.

19. National Asthma Education and Prevention Program. Expert Panel Report 3 (EPR-3): guidelines for the Diagnosis and Management of Asthma-Summary Report 2007. J Allergy Clin Immunol 2007;120(5 Suppl):S94-138.

20. Hankinson JL, Odencrantz JR, Fedan KB. Spirometric reference values from a sample of the general U.S. population. Am J Respir Crit Care Med 1999;159:179-87.

21. Weinberg EG. Urbanization and childhood asthma: an African perspective. J Allergy Clin Immunol 2000;105:224-31.

22. Addo-Yobo EO, Woodcock A, Allotey A, et al. Exercise-induced bronchospasm and atopy in Ghana: two surveys ten years apart. PLoS Med 2007:4:e70.

23. Hunninghake GM, Soto-Quiros ME, Avila L, et al. Sensitization to Ascaris lumbricoides and severity of childhood asthma in Costa Rica. J Allergy Clin Immunol 2007:119:654-61.

24. Carbajal-Arroyo L, Barraza-Villarreal A, Durand-Pardo R, et al. Impact of traffic flow on the asthma prevalence among school children in Lima, Peru. J Asthma 2007:44:197-202

25. Romieu I, Meneses F, Sienra-Monge JJ, et al. Effects of urban air pollutants on emergency visits for childhood asthma in Mexico City. Am J Epidemiol 1995; 141:546-53.

26. Noal RB, Menezes AM, Macedo SE, et al. Childhood body mass index and risk of asthma in adolescence: a systematic review. Obes Rev 2011:12:93-104.

27. Romieu I, Trenga C. Diet and obstructive lung diseases. Epidemiol Rev 2001:23:268-87.

28. Greksa LP, Spielvogel H, Paz-Zamora M, et al. Effect of altitude on the lung function of high altitude residents of European ancestry. Am J Phys Anthropol 1988:75:77-85.

29. Brody JS, Lahiri S, Simpser M, et al. Lung elasticity and airway dynamics in Peruvian natives to high altitude. J Appl Physiol 1977;42:245-51.

30. Brutsaert TD, Parra E, Shriver M, et al. Effects of birthplace and individual genetic admixture on lung volume and exercise phenotypes of Peruvian Quechua. Am J Phys Anthropol 2004;123:390-8.

31. Baumann LM, Robinson CL, Combe JM, et al. Effects of distance from a heavily transited avenue on asthma and atopy in a peri-urban shanty-town in Lima, Peru. $J$ Allergy Clin Immunol 2011;127:875-82.

32. Polosa R, Knoke JD, Russo $C$, et al. Cigarette smoking is associated with a greater risk of incident asthma in allergic rhinitis. J Allergy Clin Immunol 2008:121:1428-34.

33. Chalmers GW, Macleod KJ, Little SA, et al. Influence of cigarette smoking on inhaled corticosteroid treatment in mild asthma. Thorax 2002;57:226-30.

34. Turner $\mathbf{S}$. Exhaled nitric oxide in the diagnosis and management of asthma. Curr Opin Allergy Clin Immunol 2008;8:70-6.

35. Scott M, Raza A, Karmaus W, et al. Influence of atopy and asthma on exhaled nitric oxide in an unselected birth cohort study. Thorax 2010;65:258-62. 